TAO, Supplementary Issue, 209-230, May 2001

\title{
Subduction/collision Complexities in the Taiwan-Ryukyu Junction Area: \\ Tectonics of the Northwestern Corner of the Philippine Sea Plate
}

\author{
Shu-Kun Hsu ${ }^{1, *}$
}

(Manuscript received 26 September 2000, in final form 5 February 2001)

\begin{abstract}
The northwestern corner of the Philippine Sea plate (PSP) is actively interacting with the southwestern Ryukyu arc-trench system, as evidenced by intense seismicity. To better understand the complex tectonics of this area, we have used available $P$-wave seismic arrival times to study the velocity structures of the Taiwan-Ryukyu junction area. The result shows a prominent low-velocity structure at about 30-40 km deep beneath the Taiwan-Ryukyu region. A portion of the low-velocity structure beneath the southern Ryukyu arc west of $123.5^{\circ} \mathrm{E}$ might be interpreted as either a subducted portion of the Luzon arc or a subducted thick oceanic crust belonging to the Huatung basin. $A$ " $\Lambda$-shaped" high-velocity structure is observed at about $10-20 \mathrm{~km}$ deep in the Taiwan-Ryukyu arc junction area. Below the high-velocity structure are the plate interfaces dipping to the north and to the west. The $\Lambda$-shaped high-velocity structure upthrusts or exhumes relative to the low-velocity structure that leads the northwestward motion of the PSP. The locality of the $\Lambda$-shaped high-velocity structure coincides with the high density of earthquakes in this region. The PSP subducts northward beneath the Ryukyu arc and underthrusts westward beneath eastern Taiwan north of $23.6^{\circ} \mathrm{N}$. To accommodate the space problem in the corner of the subducting PSP, a tear fault is probably occurring at the northwestern tip of the PSP. This tear fault probably develops and propagates southeastward along an existing crustal discontinuity, subparallel to the conver * gent direction of the PSP relative to the Eurasian plate. Near $23.6^{\circ} \mathrm{N}$, a second tear fault within the PSP is proposed to separate the subducting and non-subducted portions of the Luzon arc. North of this fault, northeastern Taiwan rotates clockwise, which may be linked to the extensional regime of the southwestern Okinawa trough.
\end{abstract}

(Key words: Philippine Sea Plate, Ryukyu subduction zone, Taiwan, Tear fault)

\footnotetext{
${ }^{1}$ Institute of Geophysics, National Central University, Chung-Li, Taiwan, ROC

*Corresponding author address: Dr. Shu-Kun Hsu, Institute of Geophysics, National Central University, Chung-Li, Taiwan 32054, ROC; E-mail: hsu@oc.gep.ncu.edu.tw
} 


\section{INTRODUCTION}

The Philippine Sea plate (PSP) is surrounded by arc-trench systems except for its northwestern boundary, which abuts the Eurasian plate along the Longitudinal valley in eastern Taiwan (Fig. 1). The northwestern corner of the PSP obliquely subducts northward beneath the Ryukyu arc and overrides southwestward the Eurasian plate along the Manila trench (e.g., Angelier 1990). With respect to the Eurasian plate, the PSP moves in the direction of $\mathrm{N} 310^{\circ}$ at a rate of $71 \mathrm{~mm} / \mathrm{yr}$ in the Taiwan-Ryukyu region (Seno et al. 1993). The active interplay between the PSP and the south Ryukyu subduction zone results in intense seismicity in the Luzon and Ryukyu arcs junction area (e.g., Tsai 1986; Kao et al. 1998; Wang and Shin 1998).

At the northwesternmost corner of the PSP, the uplift of Taiwan is a typical example of modern orogeny. It is generally agreed that the formation of Taiwan started near the southem end of the Ryukyu subduction zone at about $4 \mathrm{My}$ ago (e.g., Chi et al. 1981; Teng 1990). The Taiwan orogeny is closely related to the northwestward convergence of the Luzon arc (attached to the northwesternmost PSP) against the southwest margin of the Eurasian plate (Fig. 1). Nevertheless, the mechanism for the Taiwan orogeny remains controversial (e.g., Biq 1972; Chai 1972; Jahn 1972; Juan 1975; Suppe 1981, 1984; Pelletier and Stephan 1984; Teng 1990; Lu and Hsu 1992; Hsu and Sibuet 1995; Huang et al. 1997; Wu et al. 1997; Chemenda et al. 1997; Sibuet and Hsu 1997), mainly due to the lack of observational constraints on the deep crustal structure in the Taiwan-Ryukyu junction area. In this paper, a P-wave seismic tomography study is aimed to understand the deep crustal structures in the Taiwan-Ryukyu junction area. The results, together with existing geophysical data, shed light on the complex tectonics of the northwestern corner of the PSP.

\section{DATA AND METHOD}

A unique data set of earthquake $\mathrm{P}$-wave arrival times, provided by both the Central Weather Bureau (CWB) of Taiwan and the Japanese Meteorological Agency (JMA) of Japan, was compiled for this study. There are 162 common earthquakes recorded by both the CWB and JMA, consisting of $2902 \mathrm{P}$-wave arrival times at 43 stations. However, it can be seen that the discrepancies in earthquake relocation, determined respectively by the CWB and JMA, are quite large (more than $150 \mathrm{~km}$ in the most extreme case!) (Fig. 2). This can be attributed to either the uncertainty of the velocity structures in this region or the fact that earthquakes located by the CWB or JMA were outside the appropriate coverage of each station's network. Although only 162 of the earthquakes occurring between April 1983 and September 1994 are available from both agencies, there are two advantages to using this data set. Firstly, the magnitude of earthquakes simultaneously detected by the CWB and JMA are all quite large $\left(\mathrm{M}_{\mathbf{L}}>\right.$ 4.5 ), which means that the picking errors of arrival time are relatively negligible. Secondly, the CWB network is almost perpendicular to the JMA network (Fig. 2). Using both the CWB and JMA networks results in a better coverage of seismic ray paths (Fig. 3). Consequently, this data set provides a rare but good opportunity to understand the deep velocity structures in the offshore portion of the Taiwan-Ryukyu junction area. It is also noted that existing tomographic 


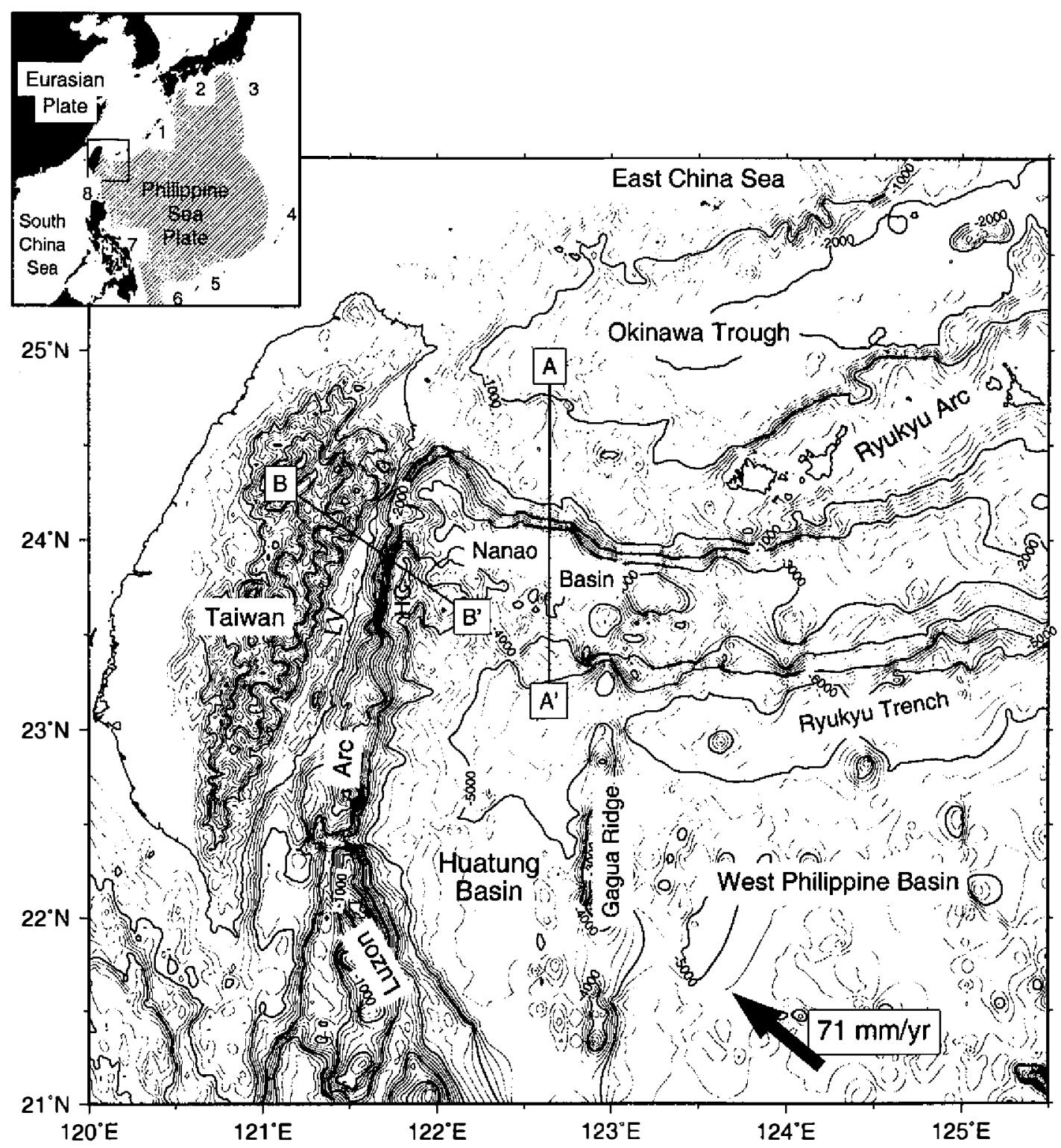

Fig. 1. Topography of the Taiwan-Ryukyu region, northwestern corner of the Philippine Sea plate (PSP; hatched area in the index map). $1=$ Ryukyu Trench; 2 = Naikai Trough; 3 = Izu-Bonin Trench; 4 = Mariana Trench; $5=$ Yap Trench; $6=$ Palau Trench; $7=$ Philippine Trench; $8=$ Manila Trench; HC = Hualien Canyon; LV = Longitudinal valley. Black arrow indicates the convergent direction of the PSP relative to the Eurasian plate. 

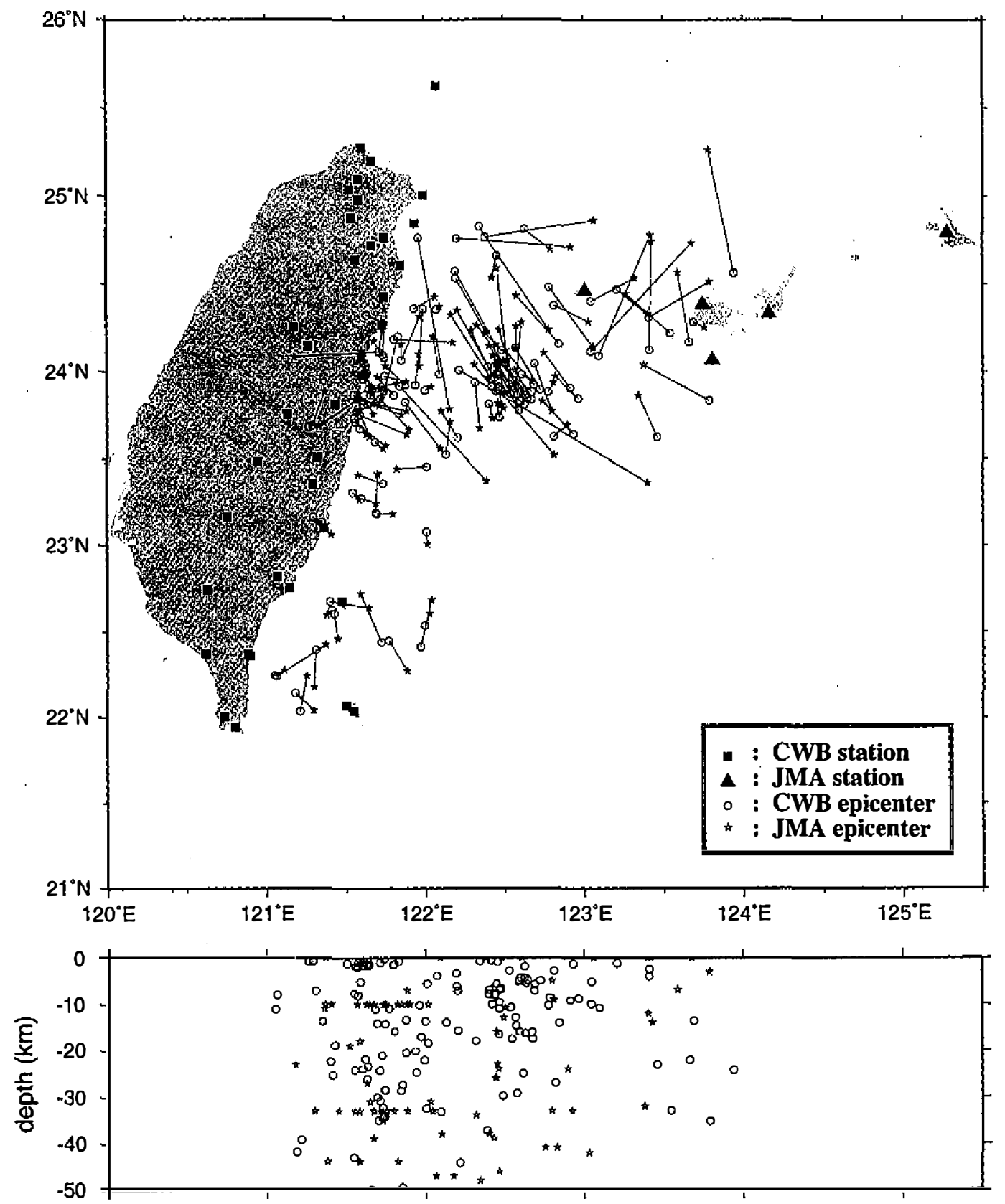

Fig. 2. The original epicenters of the common earthquakes that were located by the CWB (Central Weather Bureau) and JMA (Japanese Meteorological Agency), individually. The large difference between earthquake locations from the CWB and JMA could be due to different velocity models used by the two agencies. 


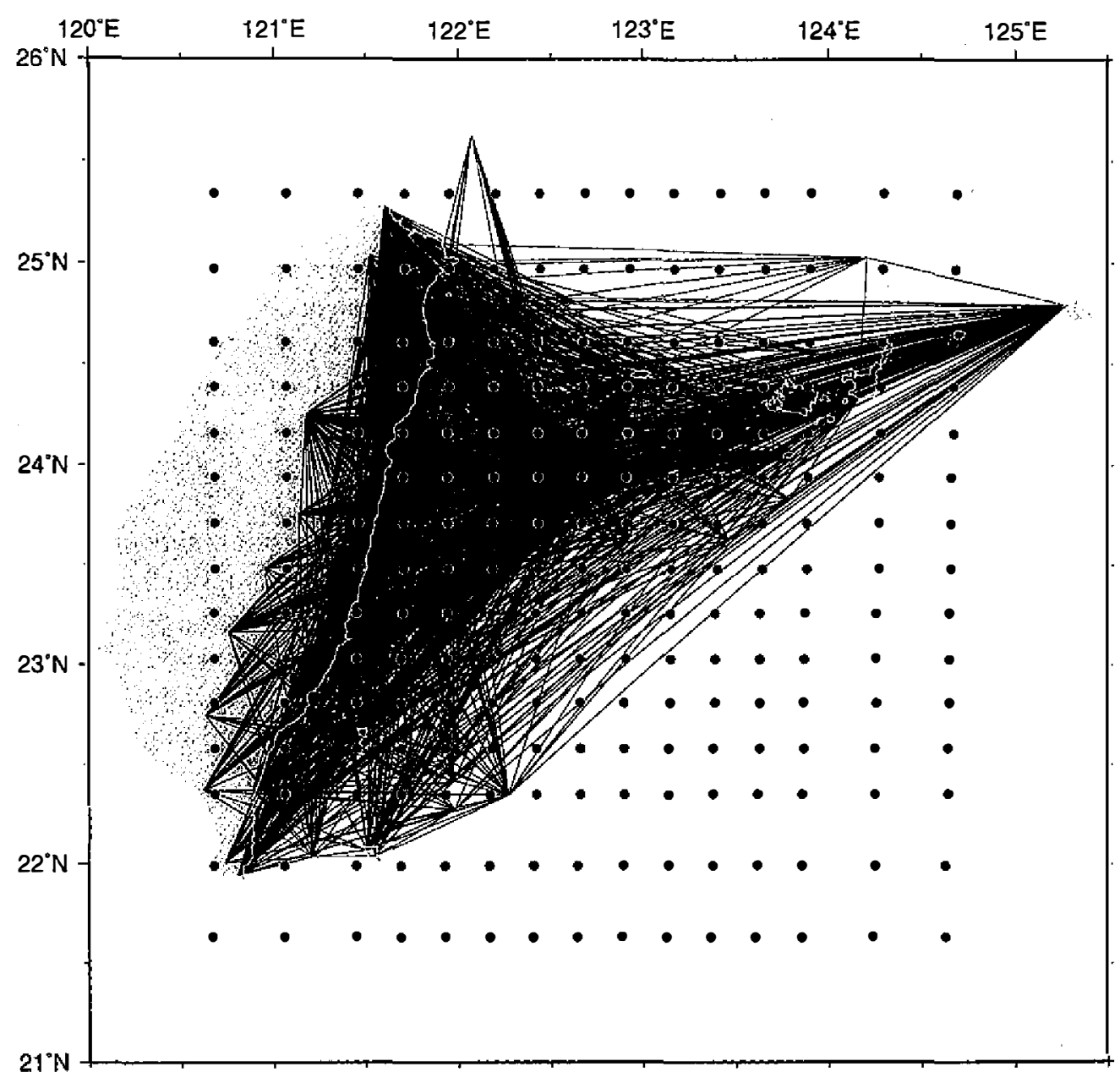

- Grid node used in the 3-D inversion

Fig. 3. Representative seismic rays between the epicenters and observed stations in Fig. 2. • = nodes used in the 3-D tomographic inversion.

models of the Taiwan area (Roecker et al. 1987; Shin and Ho 1994; Chen 1995; Rau and Wu 1995; Ma et al. 1996, Lin et al. 1998; Cheng et al. 1998) generally show poor resolution in the proposed area. Hence, this study will emphasize the velocity structures in the junction area between eastem Taiwan and the southernmost Ryukyu arc, especially the offshore portion.

The 3-D inversion code used in this study is SIMULPS12 (Thurber 1983, 1993; EberhartPhillips 1993; Evan et al. 1994). It is a simultaneous inversion for hypocenters and P-wave velocity structures. The model used by Chen (1995) is taken as an initial model. The details for the inversion technique are in Eberhart-Phillips (1993). In general, the 3-D ray-tracing algorithm can produce curved ray paths defined by points more finely spaced than the velocity nodes. The solution is obtained by iterative, damped least squares. A large damping value is 
used to reduce the degree of freedom of the solution by smoothing the solution (EberhartPhillips 1997). A suitable trade-off between data variance and solution variance could be found by different trials on the damping factor. However, considering that our data are sparse, we have used a large damping value of 200 . Based on both the size of the residual and the sourcereceiver distance, a weight is applied to each arrival time. The recording timings of both the CWB and JMA were calibrated to Global Positioning System (GPS) timing (C.-F. Chang, personal communication). The root-mean-square error for the optimum model is $0.405 \mathrm{~s}$.

The topography of the study area is complicated, varying from about $4 \mathrm{~km}$ above sea level at the summit of Taiwan, to about $6 \mathrm{~km}$ below sea level near the Ryukyu Trench (Fig. 1). To avoid a "water-quake" or an "air-quake" source, we have implemented the topographic data of Hsu et al. (1996) into SIMULPS12. Thus, each inverted hypocenter is ascertained to be within the earth. To avoid artificial structures, several grid spacings of horizontal nodes were tested. The horizontal nodes used for the final 3-D inversion are shown in Fig. 3. The vertical nodes chosen are at $0,5,10,15,20,25,35,50,70$ and $100 \mathrm{~km}$. The main result is shown in Fig. 4.

To display the resolution concisely, the spread function was calculated, which compresses each row of the resolution matrix into a single number that describes how strong the resolution is for that node (see Toomey and Foulger 1989; Michelini and McEvilly 1991). The nodes covered by a high density of rays have small spread function values and are well resolved. The calculated spread function for the final model is shown in Fig. 5. The best resolution is generally distributed in the southwest Ryukyu arc and eastern Taiwan (Fig. 5).

\section{P-WAVE VELOCITY STRUCTURES AND RELATED TECTONICS}

The most prominent feature emerging from the tomographic result is a high-velocity structure along the south Ryukyu arc and eastern Taiwan at about $15 \mathrm{~km}$ deep (i.e., the blue area in Fig. 4b). A small part of this structure in eastern Taiwan has been imaged by using highresolution local seismic array data (Lin et al. 1998). The high-velocity structure shows two remarkable velocity contrasts or changes in magnitude and direction near $121.6^{\circ} \mathrm{E}$, $24.4^{\circ} \mathrm{N}$ and $121.3^{\circ} \mathrm{E}, 23.6^{\circ} \mathrm{N}$ (as indicated by D and $\mathrm{E}$ in Fig. $4 \mathrm{c}$ ), trending more or less NWSE. Note that the distribution of the high-velocity structure displays a rough " $\Lambda$-shape" and spatially correlates with the extremely high density of earthquakes in the Taiwan-Ryukyu region (cf. Figs. $4 \mathrm{~b}$ and 6). The number of earthquakes is reduced along $\mathrm{D}$ and $\mathrm{E}$ (Fig. 6). As revealed by the locations of earthquake hypocenters collected from 1991 to 1997, the Philippine Sea plate north of D clearly subducts northward beneath northem Taiwan and the Okinawa rough (Fig. 7). Like the velocity contrast, the magnetic anomalies of the PSP suggest a prominent discontinuity along $\mathrm{D}$ (Fig. 8). To the south of D, the magnetic anomalies off eastern Taiwan generally display E-W trending features (Fig. 8), suggesting that the corresponding oceanic crust was formed in a N-S seafloor spreading context, whereas the magnetic features to the north of D generally display NW-SE trending. Moreover, the offshore portion of D is marked by a shear zone, as revealed by bathymetry (Lallemand et al. 1999).

The seismicity patterns on either side of $E$ are also different; the region immediately to the south of $E$ has fewer earthquakes deeper than $50 \mathrm{~km}$ (Fig. 7). Although the offshore portion of 

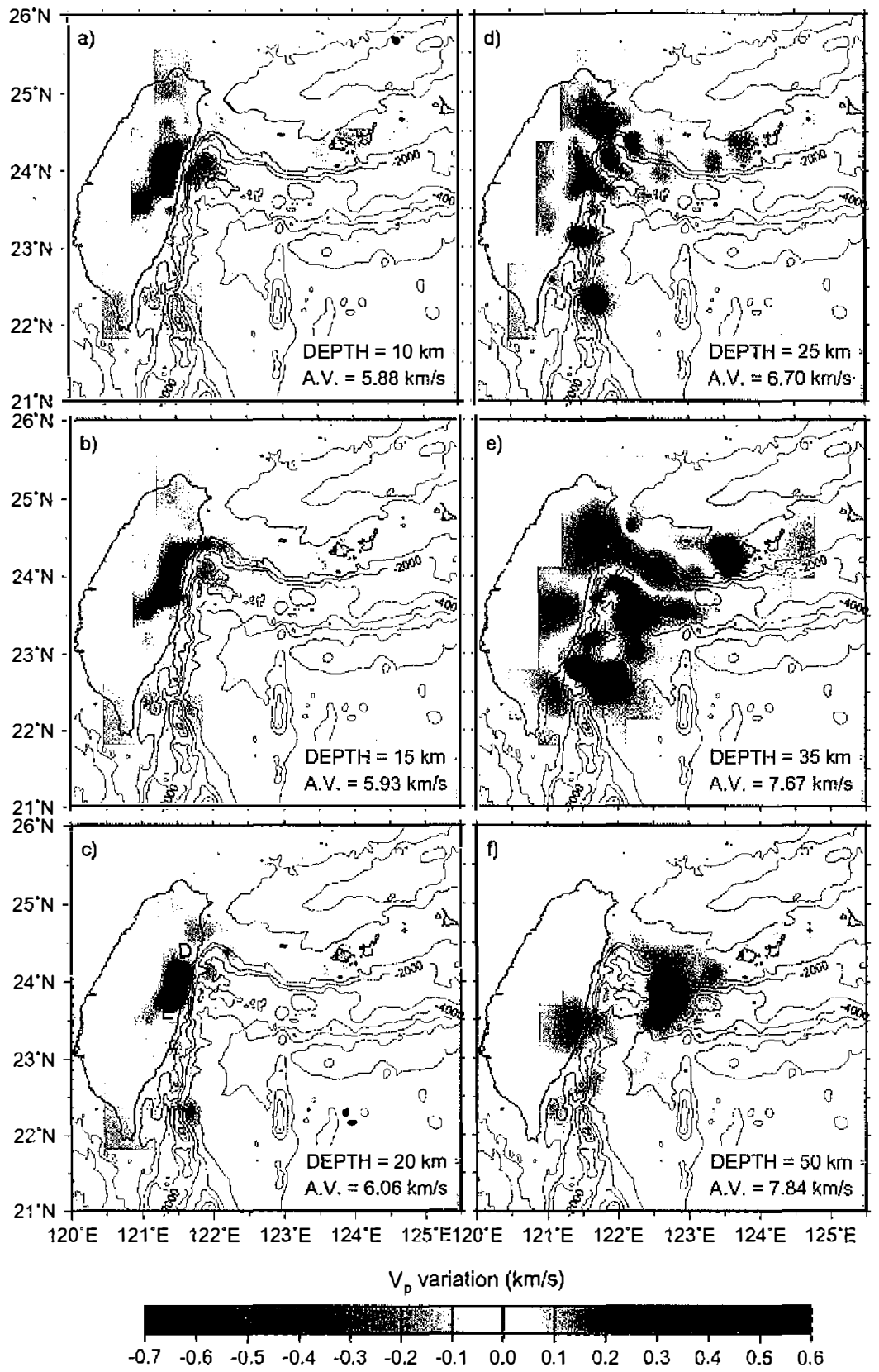

Fig. 4. The calculated P-wave velocity variation in the Taiwan-Ryukyu region. $\mathrm{D}$ and $\mathrm{E}$ indicate two velocity contrasts described in the text. The average velocity (A.V.) is the mean value of the velocity structures imaged at each depth; the imaged area at each depth includes a part of the Eurasian plate (i.e., eastern Taiwan and the south Ryukyu arc) and the northwesternmost portion of the PSP. 

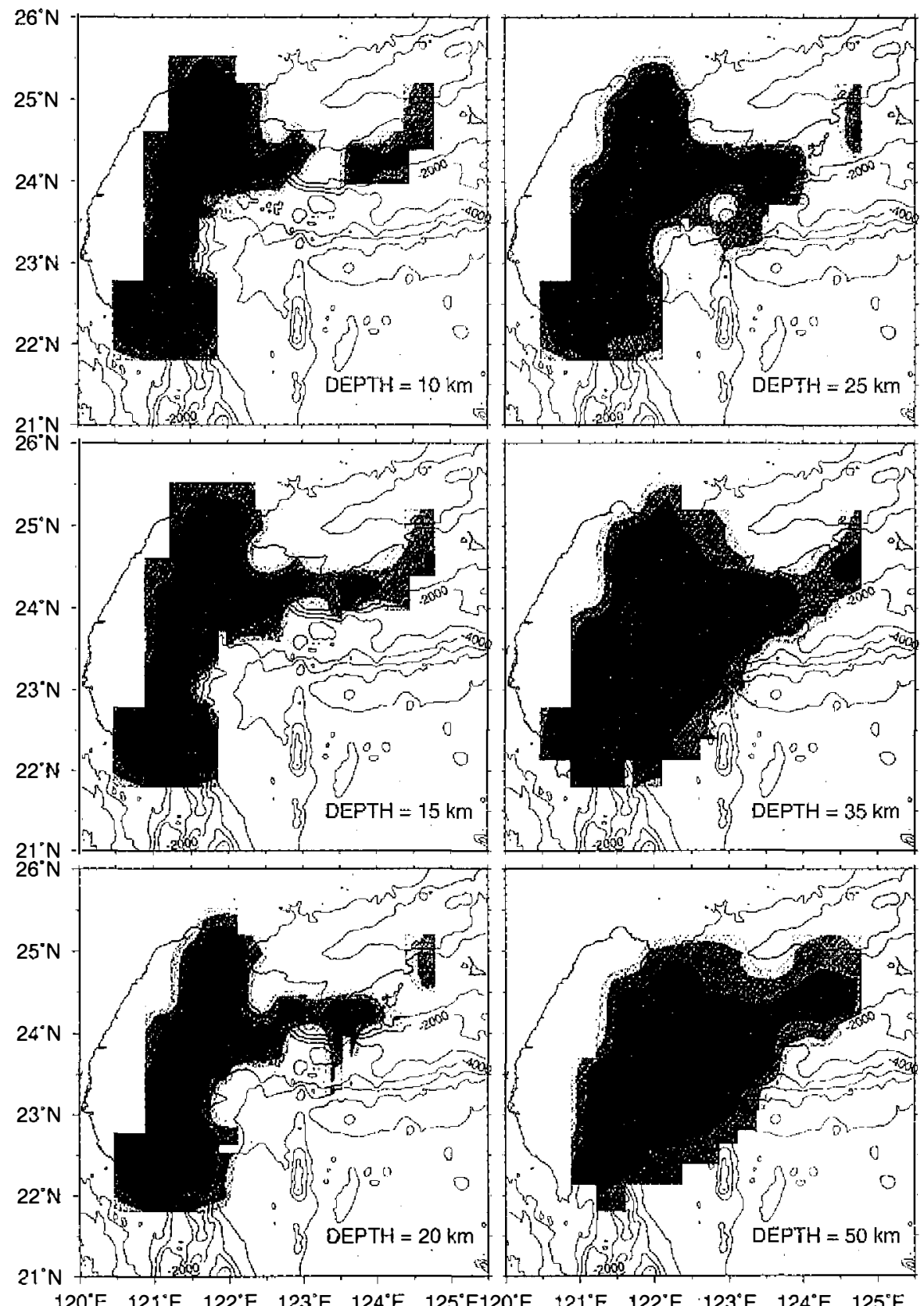

$120^{\circ} \mathrm{E} \quad 123^{\circ} \mathrm{E} \quad 122^{\circ} \mathrm{E} \quad 123^{\circ} \mathrm{E} \quad 124^{\circ} \mathrm{E} \quad 125^{\circ} \mathrm{E} 120^{\circ} \mathrm{E} \quad 121^{\circ} \mathrm{E} \quad 122^{\circ} \mathrm{E} \quad 123^{\circ} \mathrm{E} \quad 124^{\circ} \mathrm{E} \quad 125^{\circ} \mathrm{E}$

Spread function

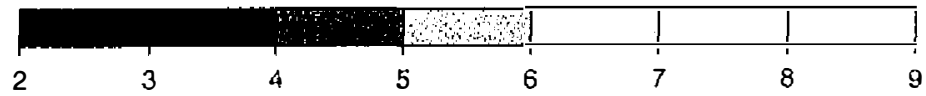

Fig. 5. The spread functions at the same depths as in Fig. 4. 

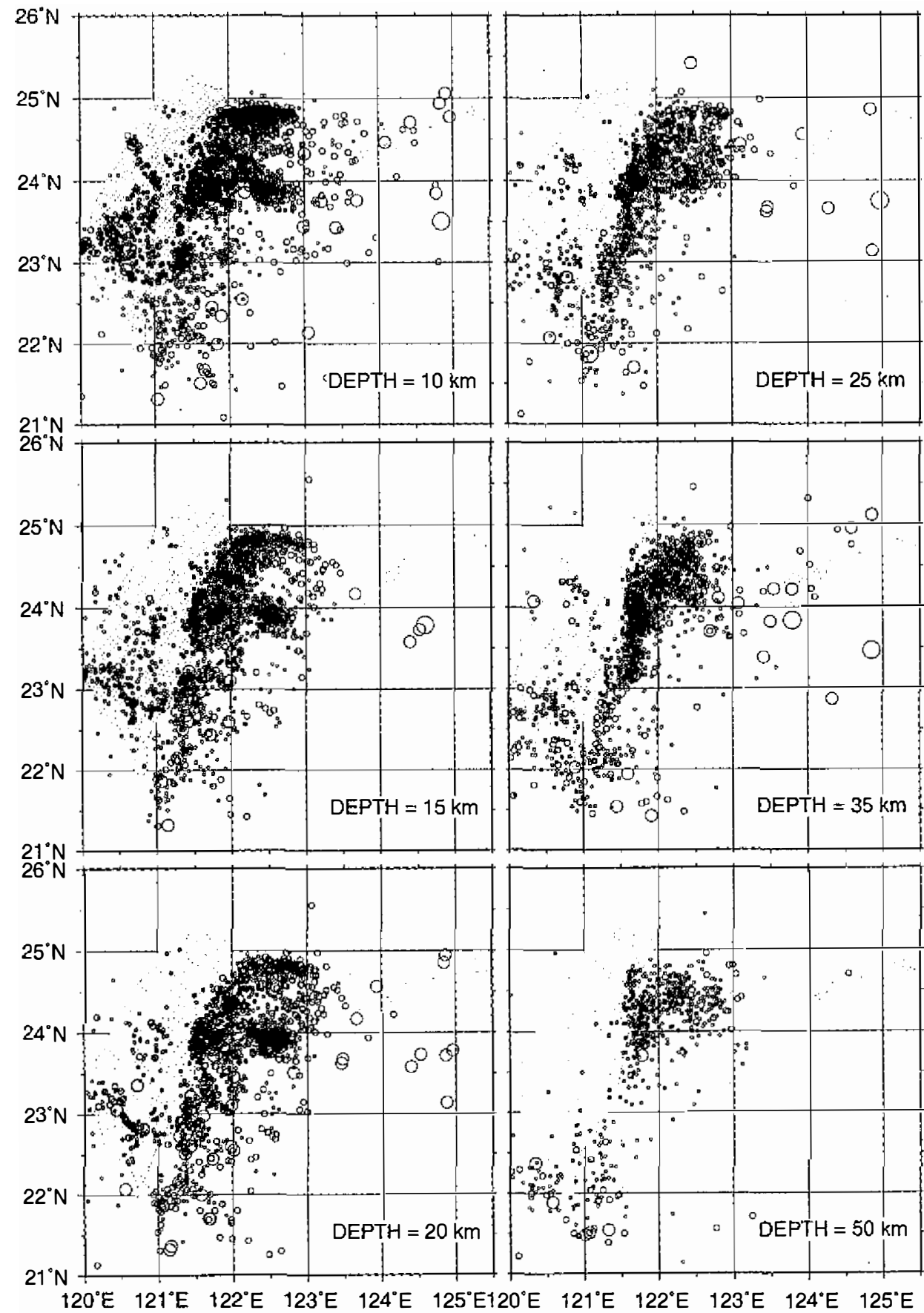
Magnitude $\left(M_{L}\right): \quad 3-4$
$\cdot 4 \cdot 5$
○ $5-6$
above 6

Fig. 6. The distribution of the earthquakes located by CWB from 1980 to 1992. 


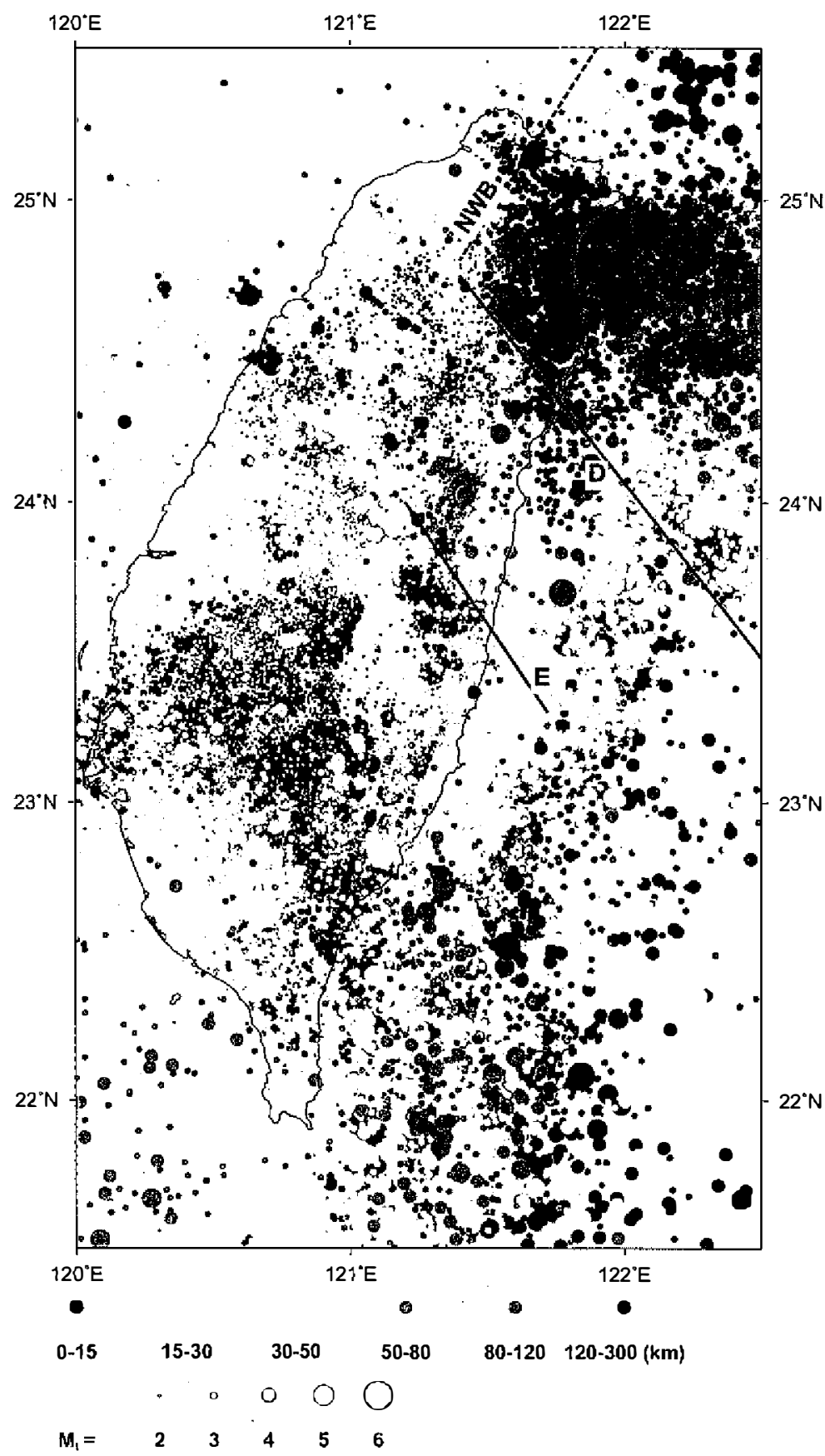

Fig. 7. Distribution of local earthquakes determined by CWB from 1991 to 1997. $\mathrm{D}$ and $\mathrm{E}$ indicale two possible crustal discontinuities within the PSP. NWB = northwestern boundary of the subducted PSP. Note that earthquake depths indicate the dipping of a subducting slab. 

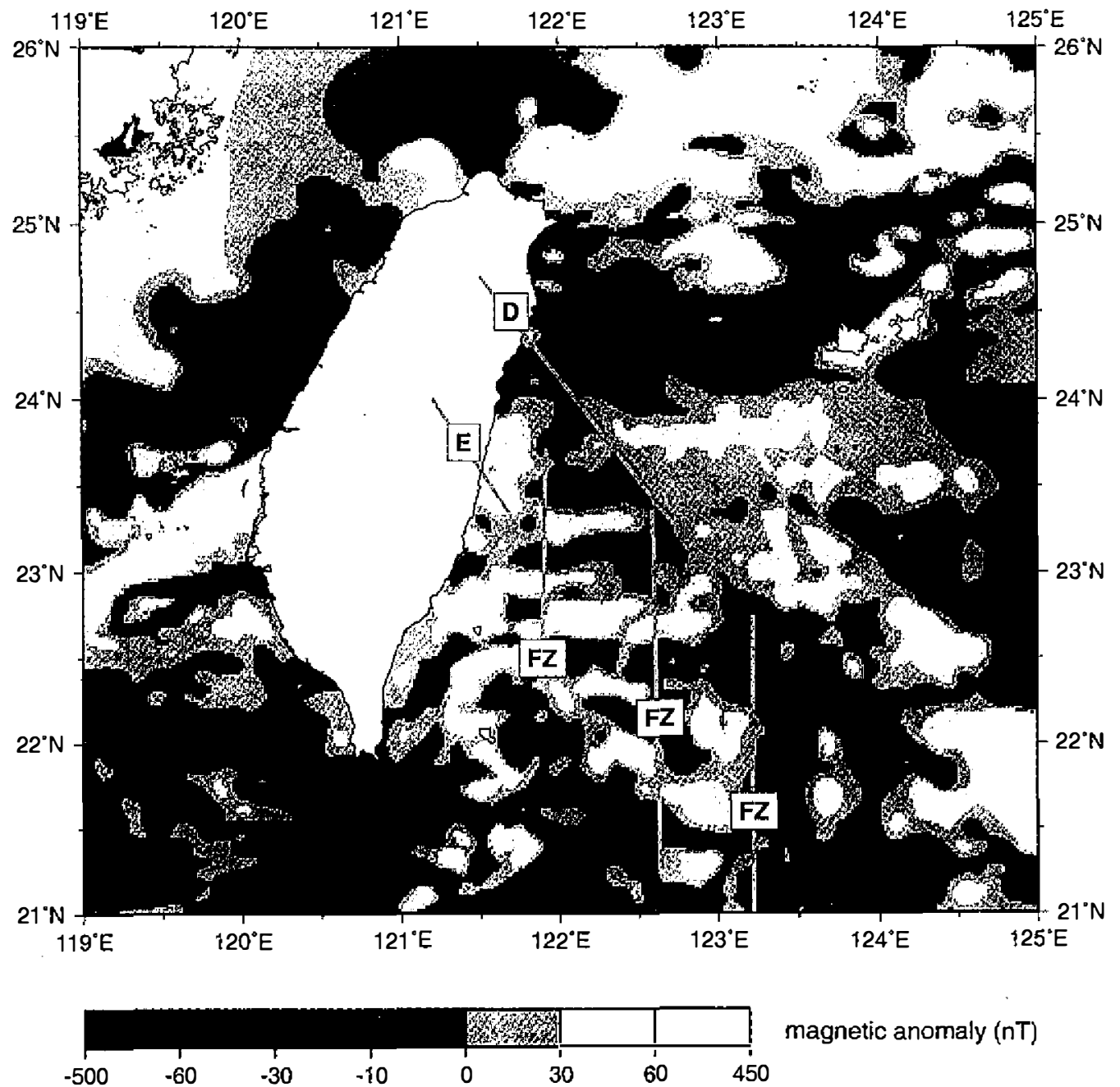

Fig. 8. Magnetic anomalies of the Taiwan-Ryukyu region (Hsu et al. 1998). FZ = old fracture zone in the Huatung basin.

E shows no obvious magnetic anomalies (Fig. 8), magnetic power spectrum analysis demonstrates that the region north of $E$ has a deeper basement than in the south (Shyu et al. 1996). In contrast, the offshore portion of $\mathrm{E}$ is marked by a negative/positive transition of free-air gravity anomalies (Fig. 9).

\subsection{A subducted Low-velocity Structure}

Beneath the $\Lambda$-shaped high-velocity structure, an obvious low-velocity structure is present at about $35 \mathrm{~km}$ deep (the red area along the south Ryukyu arc in Fig. 4e). This low-velocity structure extends along the south Ryukyu arc and dramatically disappears east of about 


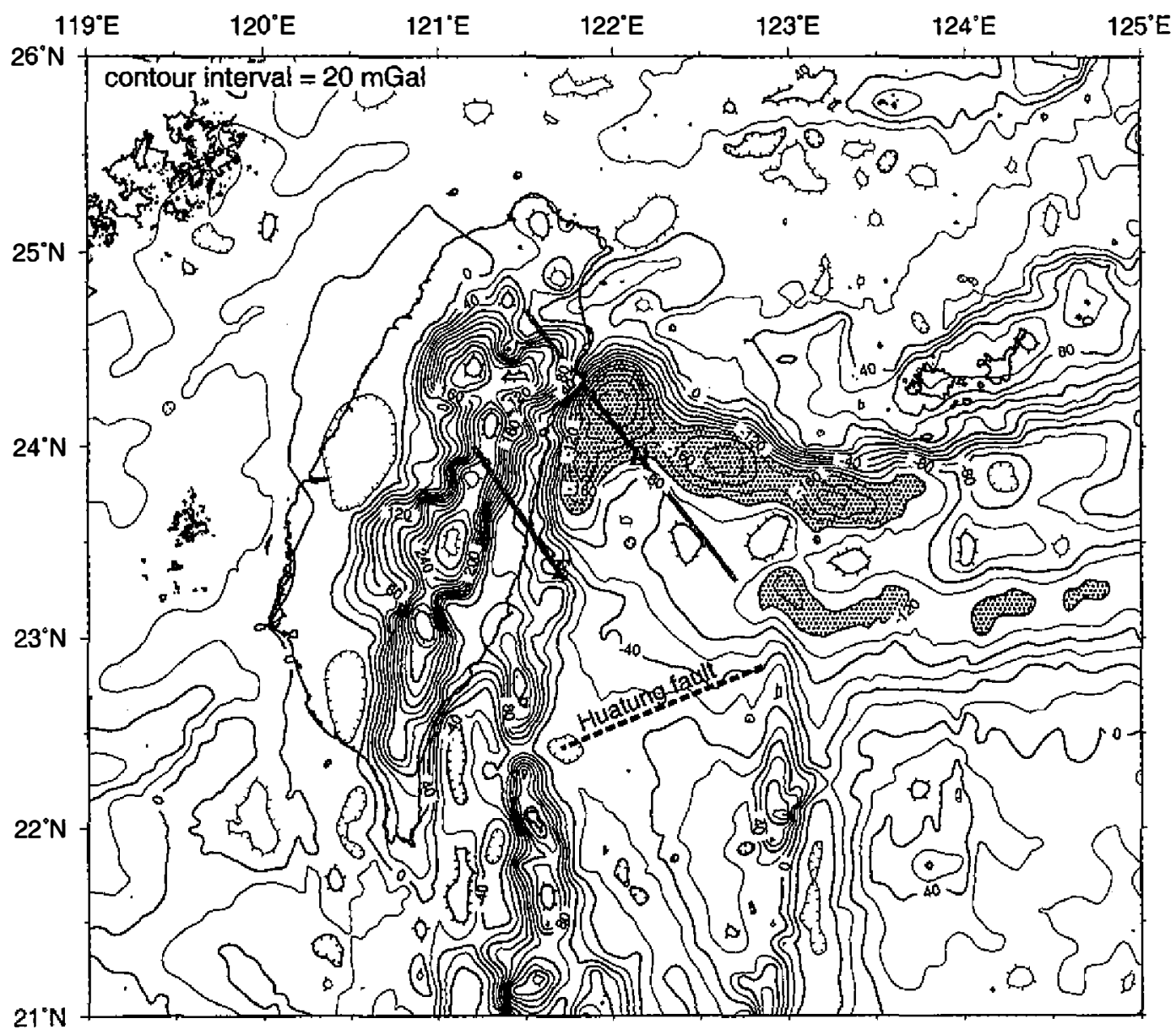

Fig. 9. Free-air gravity anomalies in the Taiwan-Ryukyu region (Hsu et al. 1998). Locations of suggested tear faults are marked by $\mathrm{D}$ and $\mathrm{E}$. Gravity anomalies less than $-120 \mathrm{mGal}$ are stippled. $\mathrm{HF}=$ Huatung fault.

$123.5^{\circ} \mathrm{E}$. Because northeastern Taiwan has a thick crust- about $40 \mathrm{~km}$ thick (e.g., Rau and Wu 1995)- the low-velocity structure beneath this region is not easily distinguishable. However, existence of a plate interface beneath the high-velocity structure is suggested by great earthquakes $\left(\mathrm{m}_{b}>5.5\right.$; red dots in profile BB' of Fig. 10), which indicate a westward underthrust beneath eastern Taiwan (Kao et al. 1998).

Because a subducted oceanic plate is usually recognized as a high-velocity feature in the upper mantle in most of subduction zones (e.g., Zhao and Hasegawa 1993), a subducted lowvelocity feature in the upper mantle, in contrast, could be ascribed to the subduction of a thick crust which resists subduction. For example, the subduction of the Chatham Rise beneath the northem South Island of New Zealand has caused a remarkable subducted low-velocity structure (Eberhart-Phillips and Reyners 1997). Accordingly, the low-velocity feature beneath the 


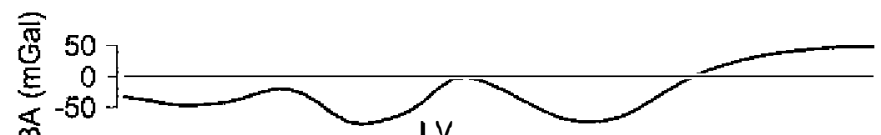

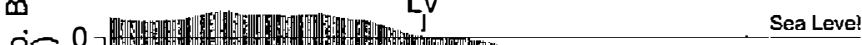

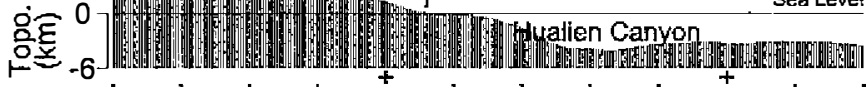

$121.5^{\circ} \mathrm{E}$ $122.0^{\circ} \mathrm{E}$
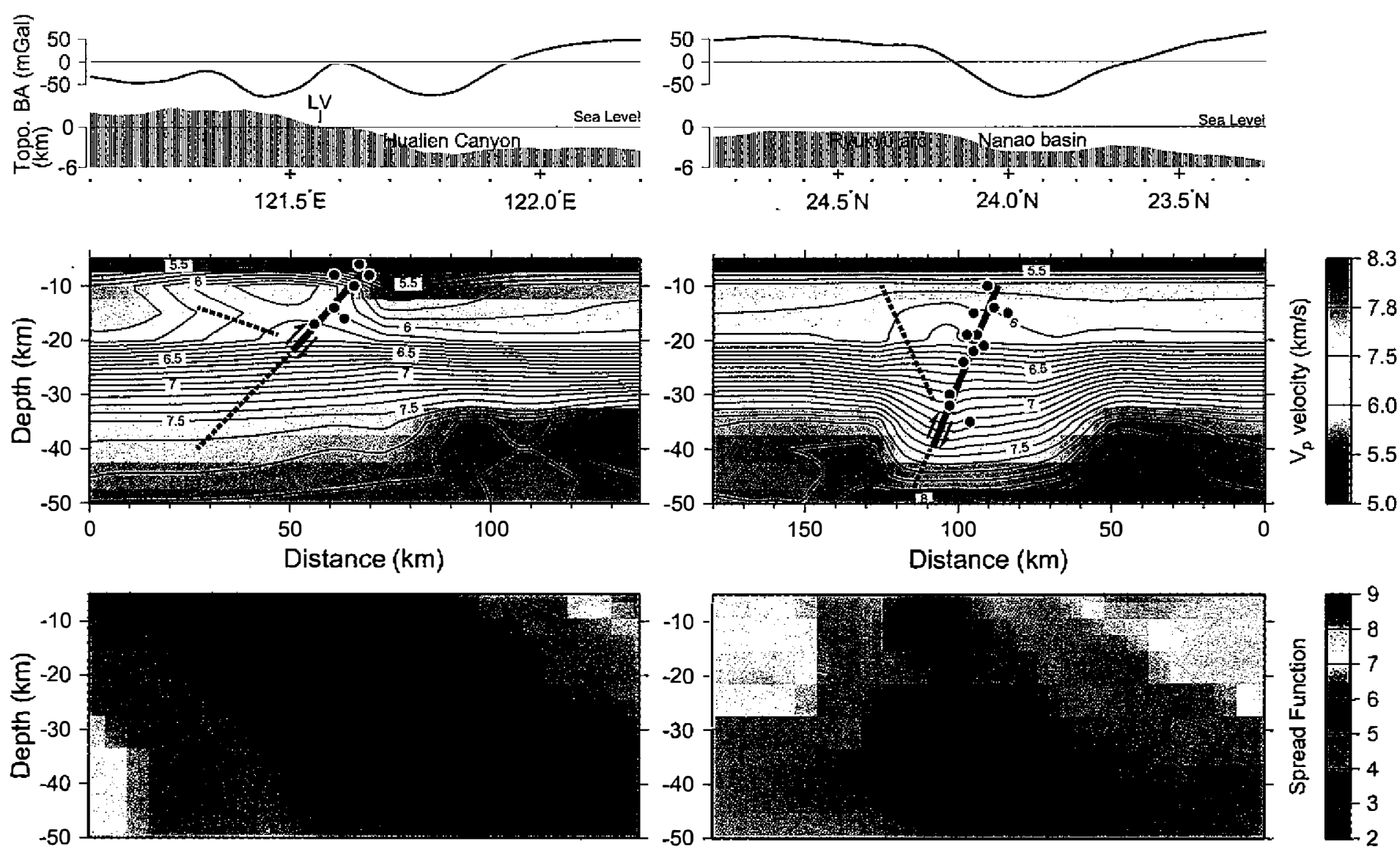

Fig. 10. Velocity distribution along profiles AA' and BB'. See profile locations in Fig. 1. The interface (blue line) between the overriding and subducting plates is suggested by tracing large earthquakes $\left(\mathrm{m}_{\mathrm{b}}>5.5\right.$; red dots) (Kao et al. 1998). Blue dashed lines indicate the possible continuations of the plate interfaces or deformation surfaces. The topographic data and Bouguer Anomalies (BA) are displayed for reference. LV = Longitudinal valley. 
south Ryukyu arc (the red area in Fig. 4e) may correspond to the subduction of a thick crust, originally belonging to the Huatung Basin (Fig. 10). Knowing the location of the interface between the overriding and undergoing plates can help us realize the nature of the low-velocity feature. For this reason, we examine a N-S trending velocity cross-section, across the Nanao basin and the Ryukyu arc (profile AA' of Figs. 1 and 10). The plate interface in profile AA' of Fig. 10 (indicated by a blue line) is traced by passing through great earthquakes $\left(m_{b}>5.5\right)$ in this region (Kao et al. 1998). The focal mechanism of each earthquake along the interface in profile AA' does display thrust behavior (Kao et al. 1998); but, its compression axis (i.e., Paxis) is generally parallel to the traced interface. This phenomenon suggests that the rupture occurring at the plate interface beneath the south Ryukyu arc and Nanao basin (Fig. 10) may be in a complex way, rather than a simple faulting along the traced interface (e.g., Font et al. 1999; Serge Lallemand, personal communication). However, it can be seen that the low-velocity structure is beneath the plate interface and subducts northward beneath the Ryukyu arc (Fig. 10). The presence of the low Bouguer gravity anomaly above the Nanao basin is in agreement with the existence of the subducted low-velocity structure (Fig. 10).

The westward underthrusting of the low-velocity structure beneath eastern Taiwan between $D$ and $E$ is suggested by both the westward dipping of the plate interface and the low Bouguer gravity anomaly over the Hualien canyon (Fig. 10). Additionally, the bathymetric slope is relatively abrupt in the nearshore region between $\mathrm{D}$ and $\mathrm{E}$ (Fig. 1). Because this main underthrusting leads the northwestward motion of the PSP and if we must have a plate boundary in this area, an initial subduction of the PSP beneath eastern Taiwan between D and E can be interpreted. As indicated by the earthquake hypocenters, the subducting PSP between D and $E$ could reach about $60 \mathrm{~km}$ in depth beneath eastern Taiwan and is deeper in the north than in the south (Fig. 7). To the south of $\mathrm{E}$, the positive free-air gravity anomalies delineate well the non-subducted portion of the Luzon arc (Fig. 9). Because the low-velocity structure is different from a typical oceanic crust and is in the northward prolongation of the Luzon arc, it could be interpreted as a subducted portion of the Luzon arc.

Shemenda et al. (1992) first interpreted the low gravity anomaly above the Hualien canyon as a result of the westward initial subduction of the PSP. They proposed a reversal subduction from east-dipping to west-dipping along the eastern flank of the Luzon arc. Conversely, because a low-velocity structure is observed below the plate interface, the Luzon arc north of E seems to have subducted beneath eastern Taiwan (profile BB' of Fig. 10). It is noted that the Luzon arc was originally formed by an eastward subduction and now the Luzon arc north of $\mathrm{E}$ is subducting westward beneath eastern Taiwan. This study suggests that the change of subduction polarity in eastern Taiwan has occurred in the former forearc region of the Luzon arc.

Because a subducting lower velocity structure can provide greater buoyancy to resisting subduction, an upward arching of the Moho in the Taiwan-Ryukyu junction area is observed (Fig. 4e). Extensional deformation associated with the upward arching of the upper part of the lithosphere is suggested by earthquake normal faulting (e.g., Kao et al. 1998).

\subsection{An Exhumed High-velocity Structure}

It is noted that the relatively high-velocity structure is sitting above the plate interface and upthrusts relative to the subducted low-velocity structure (Fig. 10). A possible thrust faulting 
or ductile deformation of the plate interface is suggested on the other side of the high-velocity structure (Fig. 10). Lin et al. (1998) calculated earthquake focal mechanisms indicating the exhumation characteristics of the high-velocity structure. Lin et al. (1998), however, suggested that the Eurasian plate in eastern Taiwan is subducting eastward beneath the PSP. In opposition to their interpretation, profile BB' of Fig. 10 shows that the exhumation of the high-velocity structure is probably caused by the existence of the low-velocity structure which leads the PSP and resists subduction westward beneath eastern Taiwan (Eurasian plate). It should be mentioned that the tomographic result of Lin et al. (1998) is limited in the onshore portion of eastem Taiwan.

\section{DISCUSSION}

\subsection{Tear Faults along Fault $D$ and Fault $E$}

As mentioned previously, it is believed that the PSP is subducting toward the north and west in the Taiwan-Ryukyu junction area. This subduction is marked by the extremely low gravity anomalies (Fig. 9). However, a subducting slab at an oceanward concave corner would cause a "space problem": an excess subducted slab would have to be compressed laterally (Chiao 1993). Thus, if the convergent direction remains constant, the excess mass may form a folded ridge-like structure from the corner. Alternatively, a tear fault within the subducting plate may be a simple mechanism to accommodate the extra material. There are three reasons why the location indicated by D could be interpreted as the trace of a tear fault (named Fault D) at the northwestern end of the subducting PSP. (1) There are different patterns of seismicity on either side of Fault D (Fig. 7), which implies a rupture within the northwestem tip of the subducting PSP. This fault may propagate southeastward as the PSP continues to move northwestward relative to the Eurasian plate. (2) It would be easier for a tear fault to occur along an existing crustal discontinuity (e.g., Cande et al. 1987; Stock and Lee 1994; Bandy et al. 1995). As shown in Fig. 8, Fault D develops along a crustal discontinuity and is rather parallel to the convergent direction of the PSP relative to the Eurasian plate (i.e., $\sim \mathrm{N} 310^{\circ}$ ). (3) On the northeastern side of Fault $\mathrm{D}$ (near $24^{\circ} \mathrm{N}$ and $121.8^{\circ} \mathrm{E}$ ), the extremely low velocity indicates a strong deposition of sediments, probably due to rapid subsidence on the northeastern side of Fault D (Fig. 4c). This subsidence, associated with rapid deposition of sediments, is confirmed by marine seismic reflection data (Lallemand et al. 1997). As a result of this tear and the northwestward motion of the PSP, the overriding plate (i.e., eastern Taiwan) could be affected. In fact, the perturbation of velocity in the direction of Fault $D$ can be seen clearly in eastern Taiwan at depths shallower than $25 \mathrm{~km}$ (Figs. 4a-4d).

Likewise, because of the different patterns of seismicity on either side of $E$ (Fig. 7), the location indicated by $E$ is possibly a fault or fault zone (named Fault $E$ ). North of Fault $E$, the subduction dips to the west while south of Fault E, the subduction dips to the east (Figs. 7 and 10 ). To accommodate the reversal of subduction polarity across Fault $E$, it is also suggested that Fault E is a tear fault. The crustal movements, estimated by the repeat GPS (Global Positioning System) measurements, show that the convergence rate across the Longitudinal valley south of Fault $\mathrm{E}$ is dramatically reduced to about half (Fig. 11) (Yu et al. 1997). In contrast, the 


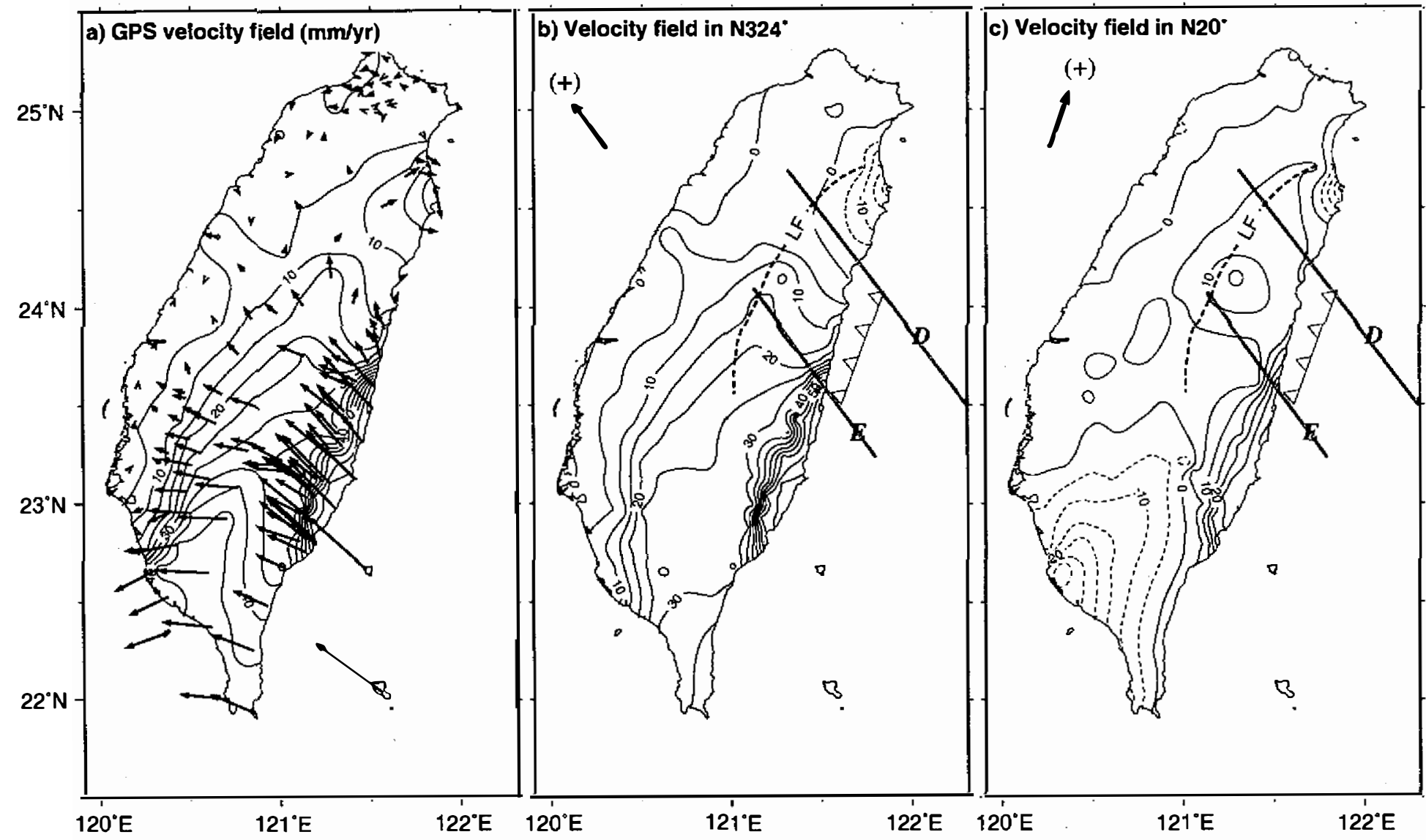

Fig. 11. The crustal movement of Taiwan derived from the repeat GPS measurements (Yu et al. 1997). a) A smoothed velocity field contoured at $5 \mathrm{~mm} / \mathrm{yr}$ intervals. The origins of the arrows are the observation points. The length of each arrow is proportional to the velocity magnitude. b) The component of the velocity field in the direction of $\mathrm{N} 324^{\circ}$. c) The component of the velocity field in the direction of $\mathrm{N} 20^{\circ}$. Note a dramatic change in velocity across Fault $\mathrm{E} . \mathrm{LF}=$ Lishan Fault. 
velocity field north of Fault $\mathrm{E}$ is almost invariant in the direction of $\mathrm{N} 324^{\circ}$ until the Lishan fault. Moreover, the magnitudes of the northwestward convergence rate decrease toward the north (Fig. 11b). This implies that the PSP subducts westward beneath eastern Taiwan gradually from $\mathrm{D}$ to $\mathrm{E}$. It agrees also with the findings that the northeast Taiwan has rotated clockwise (Lee et al. 1991). This rotation is probably associated with the backarc extension of the southern Okinawa trough (Sibuet et al. 1998). When the GPS velocity field is projected onto the direction of $\mathrm{N} 20^{\circ}$ (i.e., parallel to the Longitudinal valley), the change in velocity field across Fault $\mathrm{E}$ is still clear and it shows that a significant left-lateral shearing exists in eastern Taiwan (Fig. 11).

\subsection{Subducted Luzon Arc or Mid-ocean Ridge}

It can be seen that the present-day Luzon arc is somewhat N-S trending (Fig. 1). Thus, if the subducted low-velocity structure, beneath the NWW-SEE trending south Ryukyu arc, is interpreted as a subducted portion of the Luzon arc, its configuration raises an interesting issue: how could the originally N-S trending Luzon arc be distorted and finally emplaced beneath the south Ryukyu arc?

Hsu et al. (1996) have suggested that the south Ryukyu arc west of $123.5^{\circ} \mathrm{E}$ has been bent from a NE-SW into NW-SE direction and sheared into three blocks because of the northwestward convergence of the PSP (Fig. 1). The tomographic result suggests that the south Ryukyu arc has been sheared or stretched (Fig. 4d). However, it seems impossible that the whole PSP is distorted as the Luzon arc does. As attested by the intense earthquakes beneath the south Ryukyu arc (Fig. 5), a brittle deformation of the PSP might occur in the crustal portion linked to the subducted Luzon arc, while a ductile deformation might happen at a deeper portion allowing the PSP lithosphere to continue subducting northward. An alternative solution is that the subducted Luzon arc detached from the PSP and accreted to the bottom of the south Ryukyu arc. The latter case may be ruled out if we consider that the present-day thrust earthquakes in the south Ryukyu subduction zone mark the relative motion interface between the undergoing and overriding plates.

On the other hand, because the oceanic crust of the Huatung basin is abnormally thick (about $12 \mathrm{~km}$ ) (Yang and Wang 1998; Wang and Chiang 1998; McIntosh and Nakamura 1998), the subduction of the oceanic crust may display a relatively low-velocity character. It suggests that the low-velocity structure beneath the south Ryukyu arc may be simply a subducted oceanic crust of the Huatung basin (Fig. 12).

\section{CONCLUSION}

The tomographic results, as well as the existing geophysical data, provide the following tectonic insights into the northwestern corner of the PSP (Fig. 12).

(1) The PSP is subducting northward beneath the south Ryukyu arc and westward beneath eastern Taiwan north of Fault $\mathrm{E}$.

(2) A low-velocity structure beneath eastem Taiwan is interpreted as a subducted portion of the Luzon arc. Whereas, a low-velocity structure beneath the south Ryukyu arc could be inter- 


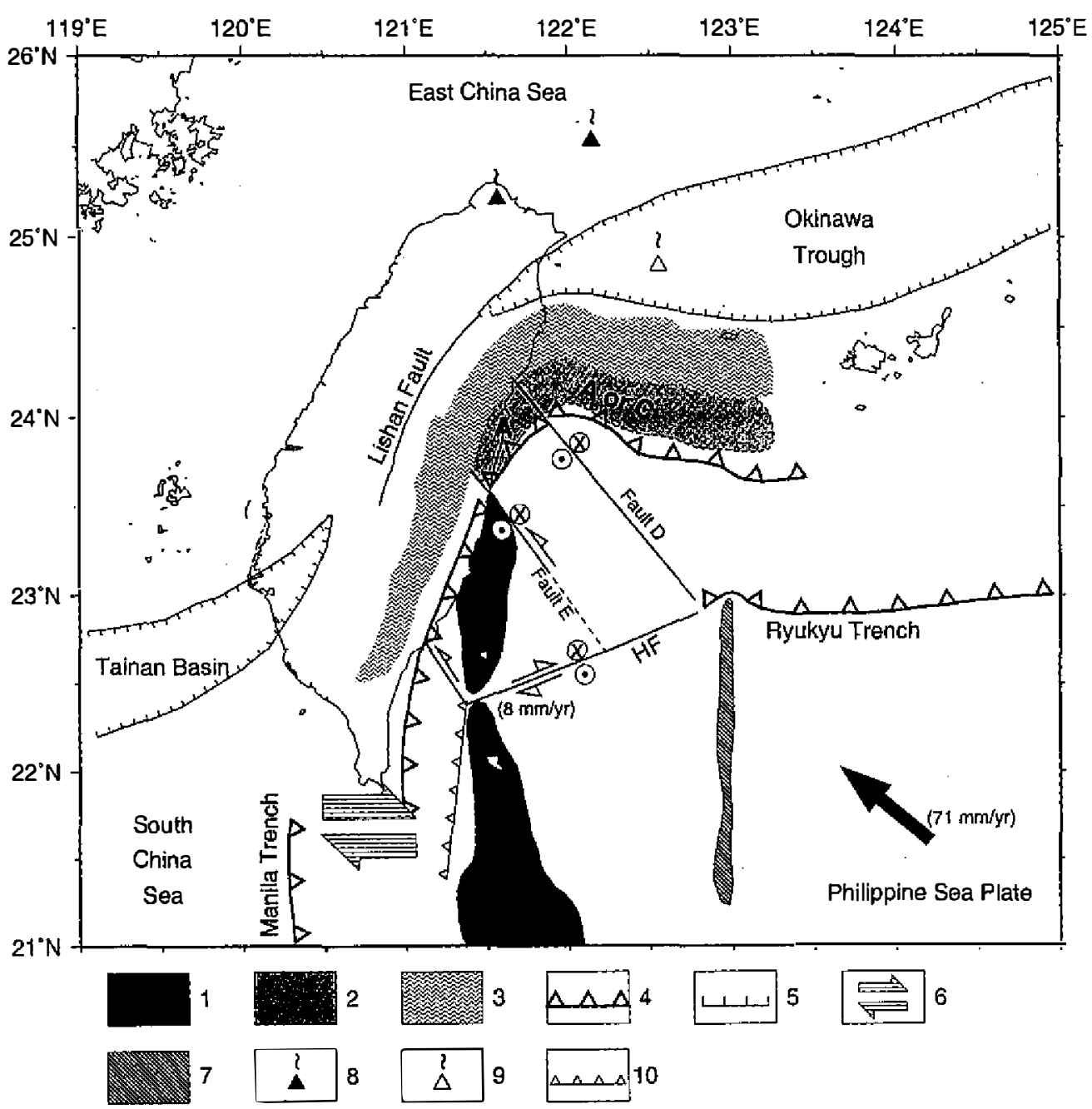

Fig. 12. Tectonic framework of the present-day Taiwan-Ryukyu region (of the Eurasian plate ) and northwestern corner of the PSP. The northwestern corner of the PSP has subsided gradually from east to west and from north to south. The relative motions between both sides of the Huatung fault (HF) were obtained by gravity and magnetic analysis (Shyu et al. 1996) and GPS velocity field (Yu et al. 1997). Noted that tear faults probably occur at the northwestern ends of Fault D and Fault E. $1=$ Luzon arc; 2 = subducted Luzon arc (indicated by letter A) or subducted oceanic crust of the Huatung basin (indicated by letter C); $3=$ Tananao Complex in eastern Taiwan and bent Ryukyu arc; $4=$ trench; $5=$ normal faults; 6 = diffusive transform boundary; $7=$ Gagua Ridge; $8=$ postcollisional volcanism (at about $200 \mathrm{~km}$ above the Wadati-Benioff zone); $9=$ recent Okinawa Trough backarc volcanism; $10=$ thrusts. 
preted as either a subducted portion of the Luzon arc or a subducted oceanic crust of the Huatung basin. The low-velocity structure beneath the south Ryukyu arc dramatically disappears east of about $123.5^{\circ} \mathrm{E}$.

(3) Above the subducted low-velocity structures, a $\Lambda$-shaped high-velocity structure is imaged. This high-velocity structure is upthrusted because of the subduction of the low-velocity structure beneath the Eurasian margin.

(4) At the northwestern tip of the PSP, a tear fault (Fault D) is probably developing along a crustal discontinuity. This tear fault within the PSP is proposed to accommodate the different degrees of the PSP subduction at an oceanward concave corner in the Taiwan-Ryukyu junction area. A second tear fault (Fault E) is proposed to accommodate the reversal of subduction polarity across Fault $\mathrm{E}$. The velocity structures of eastern Taiwan (belonging to the Eurasian plate) are perturbed by the presence of the two tear faults within the subducting PSP.

Acknowledgements Drs. Y.-M. Wu and C.-F. Chang provided earthquake data. Discussions with S. Lallemand, H. Kao, H.-S. Yu, C.-S. Lee, J.-C. Sibuet, C.-S. Liu, K.-F. Ma, P. Schnurle, W.-B. Cheng and T. Byrne are appreciated. Reviews by L.-Y. Chiao, S. Lallemand and one anonymous reviewer provided very useful remarks. This study was supported by the college of Earth Sciences, National Central University, Taiwan and the National Science Council, Taiwan, R.O.C.

\section{REFERENCES}

Angelier, J. (Editor), 1990: Geodynamic evolution of the eastern Eurasian margin, Tectonophysics, 183, 362pp.

Bandy, W., C. Morteragutierrez, J. Urrutiafucugauchi, and T. W. C. Hilde, 1995: The subducted Rivera-Cocos plate boundary: Where is it, what is it, and what is its relationship to Colima rift? Geophys. Res. Lett., 22, 3075-3078.

Biq, C., 1972: Dual-trench sucture in the Taiwan-Luzon region. Proc. Geol. Soc. China, 15, 65-75.

Cande, S. C., R. B. Leslie, J. C. Parra, and M. Hobart, 1987: Interaction between the Chile ridge and Chile trench: Geophysical and geothermal evidence. J. Geophys. Res., 92, 495-520.

Chai, B. H. T., 1972: Structure and tectonic evolution of Taiwan. Amer. J. Sci., 272, 389-422.

Chemenda, A. I., R. K. Yang, C.-H. Hsieh, and A. L. Groholsky, 1997: Evolutionary model for the Taiwan collision based on physical modelling. Tectonophysics, 274, 253-274.

Chen, Y.-L., 1995: Three-dimensional velocity structure and kinematic analysis in Taiwan area, Master's thesis, National Taiwan University, pp. 172.

Cheng, W.-B., C. Wang, and C.-T. Shyu, 1996: Crustal structure of the northeastern Taiwan area from seismic refraction data and its tectonic implications. TAO, 7, 467-487.

Cheng, W.-B., C. Wang, C.-T. Shyu, and T.-C. Shin, 1998: A three-dimensional Vp model of the southeastern Taiwan area and its tectonic implications. TAO, 9, 425-452. 
Chi, W. R., J., Namson, and J. Suppe, 1991: Stratigraphic record of plate interactions in the Coastal range of eastern Taiwan. Mem. Geol. Soc. China, 4, 155-194.

Chiao, L.-Y., 1993: Strain segmentation and lateral membrane deformation rate of the subducted Ryukyu slab. The Island Arc, 2, 94-103.

Eberhart-Phillips, D., and M. Reyners, 1997: Continental subduction and three-dimensional crustal structure: the northern South Island, New Zealand. J. Geophys. Res., 102, 11, 843-11861.

Eberhart-Phillips, D., 1993: Local earthquake tomography: Earthquake source regions, in Seismic Tomography: Theory and Practice. In: H. M. Iyer and K. Hirahara (Eds.), 613643, Chapman and Hall, New York.

Evans, J. R., D. Eberhart-Phillips, and C. H. Thurber, 1994: User's manual for SIMULPS12 for imaging Vp and Vp/Vs: A derivative of the "Thurber" tomographic inversion SIMUL3 for local earthquakes and explosions, USGS open-file Report 94-432.

Font, Y., S. Lallemand, and J. Angelier, 1999: Etude de la transition entre l'orogene actif de Taiwan et la subduction des Ryukyu - Apport de la sismicite. Bull. Soc. Geol. Fr., t170, 271-283.

Hilde, T.W.C., and C.-S. Lee, 1984: Origin and evolution of the West Philippine Basin: a new interpretation. Tectonophysics, 102, 85-104.

Hsu, S.-K., and J.-C. Sibuet, 1995: Is Taiwan the result of arc-continent or arc-arc collision? Earth Planet. Sci. Lett., 136, 315-324.

Hsu, S.-K., C.-S. Liu, C.-T. Shyu, S.-Y. Liu, J.-C. Sibuet, S. Lallemand, C. Wang, and D. Reed, 1998: New gravity and magnetic anomaly maps in the Taiwan-Luzon region and their preliminary interpretation. TAO, 9, 509-532.

Hsu, S.-K., J.-C. Sibuet, S. Monti, C.-T. Shyu, and C.-S, Liu, 1996: Transition between the Okinawa trough backarc extension and the Taiwan collision: New insights on the southernmost Ryukyu subduction zone. Mar. Geophys. Res., 18, 163-187.

Huang, C. Y., W. Y. Wu, C. P. Chang, S. Tsao, P. B. Yuan, C. W. Lin, and X. K. Yuan, 1997: Tectonic evolution of accretionary prism in the arc-continent collision terrane of Taiwan. Tectonophysics, 281, 31-51.

Jahn, B., 1972: Reinterpretation of geologic evolution of the Coastal Range, eastern Taiwan. Geol. Soc. Amer. Bull., 83, 241-247.

Juan, V. C., 1975: Tectonic evolution of Taiwan. Tectonophysics, 26, 197-212.

Kao, H., S. J. Shen, and K.-F. Ma, 1998: Transition from oblique subduction to collision: earthquakes in the southernmost Ryukyu arc-Taiwan region. J. Geophys. Res., 103, 7211-7229.

Lallemand, S. E., C.-S. Liu, and Y. Font, 1997: A tear fault boundary between the Taiwan orogen and the Ryukyu subduction zone. Tectonophysics, 274, 171-190.

Lallemand, S., C.-S. Liu, S. Dominguez, P. Schnurle, J. Malavieille, and the ACT scientific crew, 1999: Trench-parallel stretching and folding of forearc basins and lateral migration of accretionary wedge in the southern Ryukyus: a case of strain partition caused by oblique convergence. Tectonics, 18, 231-247.

Lee, T.-Q., C. Kissel, E. Barrier, C. Laj, and W.-R. Chi, 1991: Paleomagnetic evidence for a diachronic clockwise rotation of the Coastal Range, eastern Taiwan. Earth. Planet. Sci. 
Lett., 104, 245-257.

Lin, C.-H., Y.-H. Yeh, H.-Y. Yen, K.-C. Chen, B.-S. Huang, S. W. Roecker, and J.-M. Chiu, 1998: Three-dimensional elastic wave velocity structure of the Hualien region of Taiwan: Evidence of active crustal exhumation. Tectonics, 17, 89-103.

Liu, C.-C., 1995: The Ilan plain and the southwestward extending Okinawa rough. J. Geol. Soc. China, 38, 229-242.

Lu, C. Y., and K. J. Hsu, 1992: Tectonic evolution of the Taiwan mountain belt. Petrol. Geol. Taiwan, 27, 21-46.

Lundberg, N., D. L. Reed, C.-S. Liu, and J. Lieske, Jr., 1997: Forearc-basin closure and arc accretion in the submarine suture zone. Tectonophysics, 274, 5-23.

Ma, K.-F., J.-H. Wang, and D. Zhao, 1996: Three-dimensional seismic velocity structure of the crust and uppermost mantle beneath Taiwan. J. Phys. Earth, 44, 85-105.

McIntosh, K.D., and Y. Nakamura, 1998: Crustal structure beneath the Nanao forearc basin from TAICRUST MCS/OBS line 14. TAO, 9, 345-362.

Michelini, A., and T. V. McEvilly, 1991: Seismological studies at Parkfield, I, Simultaneous inversion for velocity structure and hypocenters using cubic b-splines parameterization. Bull. Seismol. Soc. Am., 81, 524-552.

Pelletier, B., and J.F. Stephan, 1986: Middle Miocene obduction and late Miocene beginning of collision registered in the Hengchun Peninsula: geodynamic implications for the evolution of Taiwan. Geol. Soc. China, 7, 301-324.

Rau, R.-J., and F. T. Wu, 1995: Tomographic imaging of lithospheric structures under Taiwan. Earth Planet. Sci. Lett., 133, 517-532.

Roecker, S. W., Y. H. Yeh, and Y. B. Tsai, 1987: Three-dimensional P and S wave velocity structures beneath Taiwan: deep structure beneath an arc-continent collision. J. Geophys. Res., 92, 10547-10570.

Schnurle, P., C.-S. Liu, S. E. Lallemand, and D. Reed, 1998: Structural controls of the Taitung Canyon in the Huatung basin east of Taiwan. TAO, 9, 453-472.

Seno, T., S. Stein, and A. E. Gripp, 1993: A model for the motion of the Philippine Sea plate with NUVEL-1 and geological data. J. Geophys. Res., 98, 17941-17948.

Shemenda, A. I., C.-H. Hsieh, and R. K. Yang, 1992: Reversal subduction and a geodynamic model of the collision in Taiwan. Acta Geol. Taiwan Sci. Rep., 30, 101-104.

Shin, T.-C., and M. Y. Ho, 1994: Three dimensional velocity structure of western Taiwan. Meteo. Bull. Central Weather Bureau, 40, 216-234. (in Chinese with English abstract)

Shyu, C.-T., M.-C. Chih, S.-K. Hsu, C. Wang, and B. Karp, 1996: Northern Luzon arc: location and tectonic features from magnetic data off eastern Taiwan. TAO, 7, 535-548.

Sibuet, J.-C., and S.-K. Hsu, 1997: Geodynamics of the Taiwan arc-arc collision. Tectonophysics, 274, 221-251.

Sibuet, J.-C., B. Deffontaines, S.-K. Hsu, N. Thareau, J.-P. Le Formal, C.-S. Liu, and ACT party, 1998: Okinawa trough backarc basin: early tectonic and magmatic evolution. $J$. Geophys. Res., 103, 30245-30267.

Stock, J. M., and J. Lee, 1994: Do microplates in subduction zones leave a geological record? Tectonics, 13, 1472-1487. 
Suppe, J., 1984: Kinematics of arc-continent collision, flipping of subduction, and back-arc spreading near Taiwan. Geol. Soc. China, 6, 21-34.

Suppe, J., 1981: Mechanics of mountain building and metamorphism in Taiwan. Geol. Soc. China, 4, 67-89.

Teng, L. S., 1990: Geotectonic evolution of late Cenozoic arc-continent collision in Taiwan. Tectonophysics, 183, 57-76.

Thurber, C. H., 1983: Earthquake locations and three-dimensional crustal structure in the Coyote Lake area, cental California. J. Geophys. Res., 88, 8226-8236.

Thurber, C. H., 1993: Local earthquake tomograpy: Velocity and Vp/Vs theory, in Seismic Tomography: Theory and Practice. In: H. M. Iyer and K. Hirahara (Eds.), pp. 563-583, Chapman and Hall, New York.

Toomey, D. R., and C. R. Foulger, 1989: Tomographic inversion of local earthquake data from the Hengill-Grensdalur central volcano complex, Iceland. J. Geophys. Res., 94, 17497-17510.

Tsai, Y. B., 1986: Seismotectonics of Taiwan. Tectonophysics, 125, 17-37.

Wang, C.-Y., and T.-C. Shin, 1998: Illustrating 100 years of Taiwan seismicity. TAO, 9, 589614.

Wang, T. K., and C.-H. Chiang, 1998: Imaging of arc-arc collision in the Ryukyu forearc region offshore Hualien from TAICRUST OBS line 16. TAO, 9, 329-344.

Wu, F. T., R.-J. Rau, and D. Salzberg, 1997: Taiwan orogeny: thin-skinned of lithospheric collision?, Tectonophysics, 274, 191-220.

Yang, Y.-S., and T. K. Wang, 1998: Crustal velocity variation of the western Philippine Sea plate from TAICRUST OBS/MCS line 23. TAO, 9, 379-393.

Yu, S.-B., H.-Y. Chen, and L.-C. Kuo, 1997: Velocity field of GPS stations in the Taiwan area. Tectonophysics, 274, 41-59.

Zhao, D., and A. Hasegawa, 1993: P wave tomographic imaging of the crust and upper mantle beneath the Japan Islands. J. Geophys. Res., 98, 4333-4353. 